\title{
ON THE GENITAL ARMATURE OF THE MALES OF GLOSSINA MEDICORUM, AUSTEN, AND GLOSSINA TABANIFORMIS, WESTWOOD.
}

By Robert Newstead, M.Sc., A.L.S., \&c.

Since the publication of my paper dealing with the taxonomic characters of the genital armature of the males of all the then known species of tsetse-flies* Mr. E. E. Austen has very kindly allowed me to examine a paratype of his Glossina medicorum; and Mr. Guy A. K. Marshall, on behalf of the Entomological Research Committee (Tropical Africa), has submitted to me the specimen of G. tabaniformis, Westwood, upon which Mr. Austen based his re-description $\dagger$ of the male of this species. I am extremely indebted to these gentlemen for giving me the opportunity of making a microscopical examination of these insects, as thereby it has enabled me to complete my observations on the male armature of the tsetse-flies, and also to complete the set of drawings illustrative of the main morphological characters of these organs.

The examination has revealed the fact that the superior claspers ( $s c$ in both figures) are free as in other members of the "fusca group" (Newstead, l.c.) but in other respects, especially in the form of the harpes, they are markedly distinct ; and these organs alone will serve as a ready means of identification : those of G. tabaniformis, being unusually complex, while those of G. medicorum are extremely simple. Apart from the structural character of the armature of the males, both sexes in G. medicorum may be distinguished by the shortness of the lateral branches of the hairs of the arista.

I do not propose in this communication to place these tsetse-flies in their relative positions in the synopsis which has already been published in the Bulletin, as, since the publication of Mr. Austen's most excellent "Handbook of the Tsetse-flies," this is quite unnecessary.

I may here add, in connection with this subject, that I have recently examined a single male Glossina palpalis, which was captured by Dr. Allan Kinghom in N.E. Rhodesia, and have found that the superior claspers of this specimen are not specifically identical with those found in the Gambia and elsewhere on the West Coast of Africa. As the microscopical preparation of the armature is not in a perfect state of preservation, I cannot yet add any further particulars; but as far as $I$ can judge at present, $I$ believe it to be representative of a distinct race.

* Bull, Ent. Res., Vol. II., p. 9, 1911.

† Handbook of the Tsetse-flies, p. 83, 1911. 


\section{Glossina tabaniformis, Westwood.}

This tsetse-fly bears a very striking external resemblance to Glossina medicorum, Austen, but is separable from the latter by its slightly longer palpi; by the characters of the armature of the male; and the greater length of the lateral branches of the hairs on the arista. The exact specific differences between these two species are set forth in the following table:-

\section{tabaniformis.}

Lateral branches of the hairs of the arista.

Harpe of male.
Very long, the terminal one about one half the length of the free end (tip) of shaft.

With four narrow, pointed appendages. medicorum.

Very short, the terminal one about one fifth the length of the free end of the shaft.

With one broadly lanceolate appendage.



Fig. 1.-Male armature of Glossina tabaniformis, Westwood ; lateral view.

Genital armature of the male (fig. 1).--Superior claspers (sc) free, of almost uniform width throughout; apices bluntly and asymmetrically bidentate; bristles very long. Inferior claspers ( $i c$ ) very broad and rather short; a few of the hairs at the margin rather long, the rest short. Median process not reaching the distal 
margin of the inferior claspers, but projecting laterally beyond the claspers on both sides. Sclerites of the juxta or penis-sheath $(j)$ branched near the anterior third. Harpes divided into four pointed processes, the basal pair being widely separated and attached to a semi-circular and narrow sclerite; the distal pair are united to a solid and somewhat rectangular process, the stem of which is attached to the semi-circular sclerite which supports the first pair of pointed appendages ; collectively these appendages are distinctly antler-like and strikingly characteristic.

The above description has been drawn up from an examination of three males as follows :--The example from which Mr. Austen drew up his description, taken at Oban, Southern Nigeria, in August, 1910 (J. H. J. Farquhar). One taken at Atta-Kwama Akapim, Densu River, Gold Coast; the third from Agbabu, Ondo District, S. Nigeria, 12. VI. 1909 (Dr. Hannington), both in the collection of the Liverpool School of Tropical Medicine.

\section{Glossina medicorum, Austen.}

Genital armature of the male (fig. 2).-Superior claspers ( $s c$ ) free, bluntly bidentate (as seen in profile) and furnished with the usual long hairs. Editum (e) with very few long hairs. Juxta $(j)$ relatively longer than in the other members

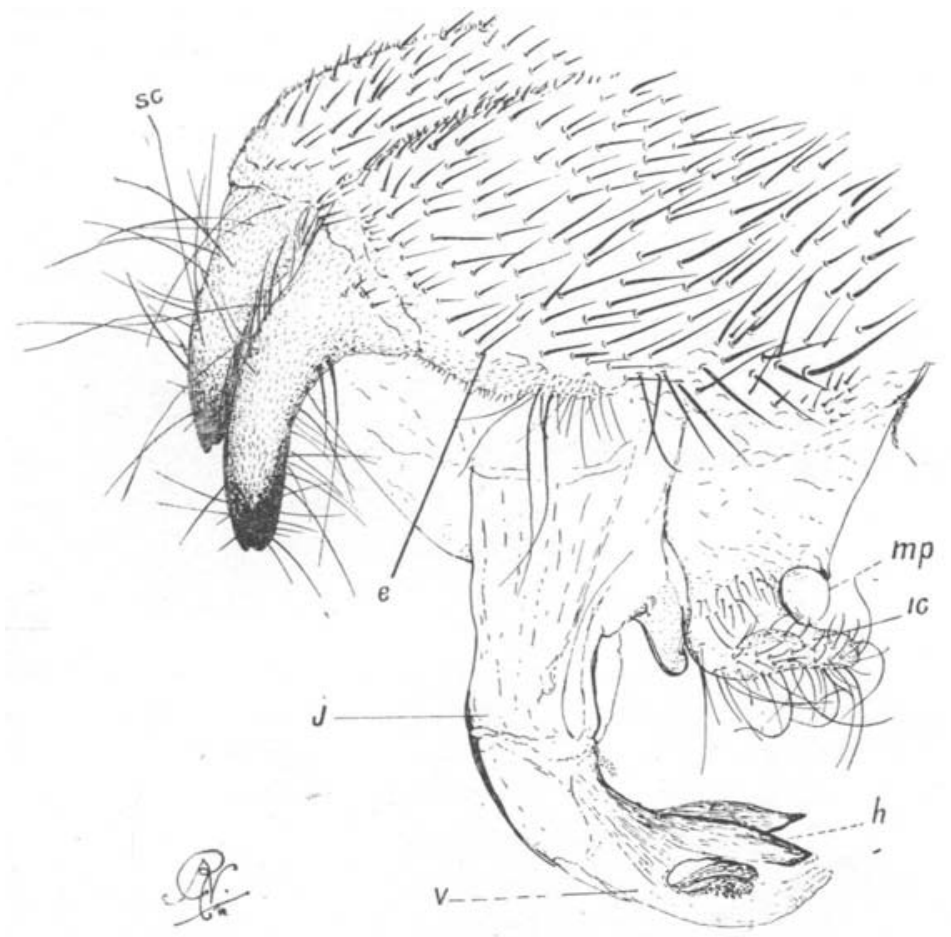

Fig. 2.-Male armature of Glossina medicorum, Austen ; lateral view,

of this group; the middle of the anterior margin with a large projecting selerite which rests or impinges upon the median process, being similar to that in G. tabaniformis but much more attenuated. Harpes $(h)$ simple and broadly 
lanceolate, apices distinctly thickened; immediately below these organs is a large dark chitinous patch, the outer portion of which is broken up into more or less isolated but minute fragments ; median process $(m p)$ very short and not extending to the margin of the inferior claspers, being visible only at the base of the latter. Inferior claspers (ic) markedly produced anteriorly.

The only male which I have so far been able to examine bore the following data:-"Glossina medicorum, Austen. Paratype. E. E. A. 8. III. 1911. Sanguin R., Liberia, W. Africa, 27. XI. 1908. Surg. A. McCloy, R.N., 1909-1."

20th May, 1911. 